February 2018

\title{
Use of House Arrest In The Context of the Respecting the Constitutional Rights of an Individual in Russia
}

Svetlana Afanasieva 2365999

Perm State University, polsvetlana@yandex.ru

Irina Kilina

Perm State University

Follow this and additional works at: https://commons.erau.edu/jdfs|

Part of the Computer Law Commons, and the Information Security Commons

\section{Recommended Citation}

Afanasieva, Svetlana 2365999 and Kilina, Irina (2018) "Use of House Arrest In The Context of the Respecting the Constitutional Rights of an Individual in Russia," Journal of Digital Forensics, Security and Law. Vol. 12 : No. 3 , Article 12.

DOI: https://doi.org/10.15394/jdfsl.2017.1496

Available at: https://commons.erau.edu/jdfsl/vol12/iss3/12

This Article is brought to you for free and open access by

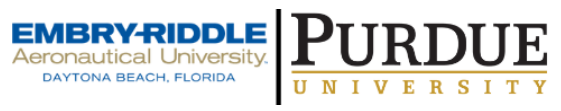
the Journals at Scholarly Commons. It has been accepted for inclusion in Journal of Digital Forensics, Security and Law by an authorized administrator of Scholarly Commons. For more information, please contact commons@erau.edu.

(c)ADFSL 


\title{
USE OF HOUSE ARREST IN THE CONTEXT OF THE RESPECTING THE CONSTITUTIONAL RIGHTS OF AN INDIVIDUAL IN RUSSIA
}

\author{
Svetlana Afanasyeva \\ Irina Kilina \\ Perm State University \\ Perm, Russia
}

\begin{abstract}
The author analyzes the selection of preventive measures in the form of house arrest in Russian criminal proceedings on the basis of universal and European standards of guaranteeing respect for individual rights. The article says that the application of preventive measures significantly restricts the right to protect the dignity of the individual, the right to freedom and personal inviolability, the right to move freely, choose the place of residence and residence. The author defends the alternative when applying preventive measures in the form of house arrest. This preventive measure, unlike detention, home arrest does not provide for the isolation of a person from the usual conditions of daily existence and to a greater extent guarantee the rights of citizens before the court decision.
\end{abstract}

Keywords: inviolability of the person, legal guarantees, preventive measures, house arrest

\section{LITERATURE REVIEW}

The legislation of the Russian Federation in the framework of global and European standards of respect the rights of the individual warranty restriction allows only in exceptional cases, subject to justification and proper procedures for such restrictions. The use of coercive measures, including preventive measures, very severely limits one of the most important constitutional rights of an individual - the human right to protect dignity, the right to liberty and security of a person, the right to move freely, choose their place of residence. Art. 21, 22, 27 of the Constitution of the Russian Federation (The Constitution of the RF, 1993).
Therefore, the legislator provides for alternativeness in electing the preventive measures (art. 98 of the $\mathrm{CPC}$ of the RF) in criminal proceedings. Taking into account the particular circumstances of a criminal case, it is possible to select such a measure, which creates optimal conditions for evidence in the criminal cases to ensure the rights of the accused (suspect) to a maximum.

In practice, detention as a preventive measure is often used by Russian law enforcement agencies. According to the judicial department at the Supreme Court of the Russian Federation, in 2015 year the courts considered 154260 motions of preliminary investigation bodies to apply a preventive measure in the form of detention and granted 140457 (Report on the work of the courts. 
2015). In the first half of the year 2016 they reviewed 70293 motions and satisfied 63556 of them (Main statistical indicators of the courts. 2016).

Analyzing data of judicial practice of one of the constituent entities of the Russian Federation, the Permsky Krai, sure, we can note a similar trend related to the application of detention as a preventive measure.

In 2011 the courts in Perm considered 5 235 motions of preliminary investigation bodies regarding the election of the preventive measure of remand detention, and satisfied 4 $428(84.6 \%)$, in $2012-5151$, satisfied - 4240 $(82.3 \%)$ in the year $2013-4496$, satisfied -3 $756(83.5 \%)$ (Main statistical indicators of the courts. 2013), $2014-3809$, satisfied - 3197 $(83.9 \%)$, in the year $2015-3543$, satisfied -4 $(84.8 \%)$ (Main statistical indicators of the courts. 2015).

In addition, in the course of the criminal trial, in accordance with Art. 255 of the Code of criminal procedure the district courts, magistrates of Perm Krai, applied detention for 768 persons in 2011, for 654 persons in 2012, for 618 persons (Main statistical indicators of the courts. 2013) in 2013, 522 persons in 2014 and for519 individuals in 2015 (Main statistical indicators of the courts. 2015).

It should be said about the election of the detention of a juvenile accused (suspected). So, in 2011 the year the courts of Perm Krai 217 motions considered the preliminary investigation bodies regarding the election of a preventive measure in the form of detention, one of them is satisfied with $148(68.2 \%)$; in the year 2012 - 129 , granted-86 $(66,7 \%)$, in the year 2013 - 119, satisfied - $92(77,3 \%)$ (Main statistical indicators of the courts. 2013), in $2014-74$, met $-56(75.7 \%)$, in $2015-58$, met - $40(69 \%)$ (Main statistical indicators of the courts. 2015).
The European Court of human rights often receives complaints from Russian citizens in detention, violations of Articles 3 and 5 of the European Convention for the protection of human rights and fundamental freedoms (Convention. 1950). In particular, the application of inhuman and degrading treatment through deprivation of food, sleep, illegal and unwarranted detention, unlawful extension of detention, caused by the inefficiency of the investigation in the criminal case (Evgeny Gusev v. Russian Federation. 2013). In the legal literature provides evidence that Russia had already delivered more than 110 regulations on such complaints, about 700 cases were pending before the European Court (Zjablina, M. 2016).

\section{A HOUSE ARREST AS AN ALTERNATIVE TO DETENTION IN THE CRIMINAL LITIGATION}

In 2001, the Code of criminal procedure included house arrest as an alternative to detention in the criminal litigation. (art. 107 of the code of criminal procedure). The most complete summary of the procedural order of the application of this preventive measure was legislated only after the adoption of the Federal law of the Russian Federation of 07.12.2011 ㄲo 420-FZ, which was included in the new wording of art. 107 of the Code of criminal procedure. The essence of this preventive measure is to directly limit the right to freedom and inviolability of the person of the accused (suspect), under the protection of Art. 21, 22, 27 of the Constitution of the Russian Federation. For this reason, house arrest is chosen, and it is used only by the Court in the adversarial procedure and on specific, specially established term. Unlike detention, house arrest does not isolate an 
individual from the usual conditions of daily life.

House arrest can be selected as a preventive measure, if it is not possible to use the collateral or other softer measure. When deciding on house arrest, a court may rule, depending on the severity of the charges, the facts of the case and the datax of the identity of the accused (suspect), and expose all constraints and (or) prohibitions listed in Chapter. 7 Art. 107 of the Code of criminal procedure, or some of them.

But as practice shows, house arrest is not regarded to have proper attention, unlike exclusive preventive measure (detention). According to the judicial department at the Supreme Court of the Russian Federation, house arrest in Russia was applied in 1346 cases in 2011, in 2714 cases in 20112, in 3086 in 2013 (Statistics for the of the Supreme Court of RF. 2013). In 2015 the courts of the Russian Federation considered 5294 motions of preliminary investigation bodies to apply a preventive measure in the form of house arrest and satisfied 4676 of them. In the first half of 2016 they considered - 3280 motions and satisfied 2901 (Main statistical indicators. 2016).

In 2011 The courts of Perm Krai used preventive measure in the form of house arrest against 9 persons, in 2012 - against 15 persons17, 2013 - 49 against persons, in 2015 against 219 persons (Main statistical indicators. 2015).

Thus, the number of accused (suspected) under house arrest, is gradually increasing. However, the number of persons in respect of whom the most severe measure was used remains significant, and house arrest has not become a widespread measure yet.

Many prominent Russian scholars, employees of law enforcement agencies and representatives of the legal community have pointed out that in order to improve the effectiveness of the use of house arrest as a preventive measure, above all, it is necessary to develop more detailed legal regulation of selection and application of this measure. First and foremost, on the legislative level delineate clearly the grounds and conditions for the use of house arrest and detention should be distinguished, specifying under what circumstances the application of the preventive measure of remand detention is inappropriate and against a person accused (suspected) of committing a crime, will apply more effectively house arrest. Thus it is necessary to consider the legal position of the Constitutional Court of the Russian Federation, as set out in the Decree of $03 / 22 / 2005$, no. 4 -p: rules on election security measures «do not imply the possibility of a court decision on the above subject without research submitted by parties to the prosecution and defence evidence confirming the presence or absence of the grounds for the application of this preventive measure» (Decision of the Constitutional Court of the RF. 2005).

In practice there are cases where the accused (suspect)'s detention is applied, but there is a reason to select a softer measure such as house arrest, in particular. So, the ruling of the Judicial Board on criminal cases of Permsky Krai Court of 25.06.2013 upheld the decision of judge of Sverdlovsk District Court in Perm on detention in respect of the accused and ordered to apply house arrest. The Court of Appeal explained it by the fact that the Court of First Instance did not give proper evaluation, as required by the provisions of Art. 99 of the Code of criminal procedure, and aggregated information about the identity of the suspect. The Board agreed on the possibility of softer penalties for the accused and determined that the preventive measure of remand detention would be replaced by home arrest (Appellate decision. 2013). 
The decision of appeal by Judicial Board on Criminal Cases of Perm Krai Court changed the ruling of the judge of the Leninsky District Court of Perm on the application in respect of a person accused of an offence of medium gravity, the preventive measure of remand detention should be changed to house arrest. The Court of appeal did not find the reasoning of the District Court that the defendant presents exceptional public danger and should be detained, justified. There was no evidence that the accused might put pressure on other participants in the proceedings and prevent the preliminary investigation, in the materials of the criminal case. In such circumstances, the Court of appeal against changed from detention to house arrest (Appellate decision. 2014).

Thus, the courts taking the decision on election of a preventive measure in the form of detention, which is the most severe in the criminal process, do not always adequately and comprehensively study the materials of the criminal case. This, in turn, questions the validity of the decision and, as a rule, leads to changes in the rendered decision by the higher court.

In the selection of house arrest as a preventive measure it is essential to identify the categories of persons to whom this priority could be applied before house arrest. Suggestions in the literature are about disabled, minors, pregnant women and women with minor children (Tkachev, N. 2003). In doing so, these persons should be determined on the basis of the categories of the offences, of which they are accused (suspected), the presence or absence of convictions, compensation, recognition of guilt by the accused (suspect) and other circumstances.

Another essential reason for choosing house arrest is to establish the whereabouts of the accused (suspect) in its application, since it will actually draw the boundaries of their freedom. This was noted at the Plenum of the Supreme Court of the Russian Federation in the Decreeing of 19.12.2013. № 41 (Decision of the plenum of the Supreme Court of the RF. 2013). Such a place is a dwelling in which the accused (suspect) lives as an owner. a tenant or on other legal grounds.

In practice, there may be situations where the accused (suspect) could not provide the court with documents proving his ownership or lease of residential premises. We think that in this case the Court may use other evidence as a basis for deciding on house arrest. The law contains no direct reference to this possibility. But according to paragraph 38 the Plenum of the Supreme Court of the Russian Federation of 19.12.2013 No 41 in electing a preventive measure in the form of house arrest, the owner of the dwelling should be involved in the trial, if he or she lives in the room where the plan to locate the suspect or the accused during the house arrest. The testimony of the owner can be used as an evidence confirming the legality of residence of a citizen in a residential place.

The list of «other» legitimate grounds remains open. In particular, such grounds could include location of a foreign citizen or stateless person's premises other than a place of residence, as well as other indoor, institution or organization in which the foreign citizen or person without citizenship is and (or) at which a foreign national or a stateless person shall be subject to the registration of the place of stay (Federal law of the RF" On migration registration...". 2015).

Choosing house arrest as a preventive measure, we must consider the rights of family members of the accused (suspect), who live in the same residential premises.

Certainly, a significant achievement of the legislator was an indication that house arrest may only be applied provided that the premises is residential, i.e. meets the necessary 
sanitary or technical requirements that allow for human vital activity for an extended period of time.

Taking into account the State of health of the accused (suspect) the place of his detention under house arrest can be determined by the medical establishment (Resolution of Government of RF. 2011). As an institution it is necessary to understand the medical organization of the public health and municipal health care system, providing the treatment of a citizen (Federal law of the RF. 2011). According to para. 11 Art. 107 of the Code of criminal procedure in case of hospitalization of a person taken under house arrest, the place of performance of a preventive measure in the form of house arrest is considered to be the territory of the relevant health agencies. Does it mean that the location of the persons taken under house arrest, in such cases, will be the entire territory of health agencies? It is obvious that in this part of the provision of this article requires detail, because the necessary degree does not allow to isolate the accused (suspect) from society.

It is worth noting that, in practice, there arises another problem related to the location of the accused (suspect) in the election of house arrest. Free migration there are often situations when crimes are committed by individuals from another municipality, the subject of the Russian Federation or any other State. In this case, the preliminary investigation bodies almost always seek to elect a preventive measure in the form of imprisonment, although in fact it remains a possibility for the use of house arrest. The logics of the law enforcement in this case is understandable: If the accused (suspect) goes to another region, then they can escape from prosecution. In this context, to extend the application possibilities of house arrest as a preventive measure for State and municipal bodies and services should provide housing and to place at the disposal of law enforcement agencies a certain number of dwellings that meet the established sanitary and technical requirements. In such a case, the preliminary investigation bodies will be able to petition the Court for the election of the accused (suspect) house arrest that will respect the constitutional rights of the individual and promote humanization of criminal proceedings.

In the election of the accused (suspect) house arrest as a preventive measure raises an urgent question: what is their isolation from society? The law does not define the term «isolation», but indicates that it may be total or partial. I assume that the «isolation» should be understood such restrictions on freedom, which is a necessary contribution to the investigation of a crime and did not allow the suspect or accused to counteract the production of investigation of the criminal case. Of course, in the modern period of development of information technologies complete isolation of the accused (suspect) from society is impossible due to the following reasons.

Firstly, modern development of mobile telephony and the Internet "gives the opportunity to the accused (suspect) to communicate freely through these technical means with others that are sometimes difficult to control prison staff inspections. Secondly, the judgement on the election of house arrest as a preventive measure does not provide a basis for monitoring and recording of telephone and other conversations, and to obtain information about the connections between subscribers and/or subscriber devices. Thirdly, it should also be borne in mind that because this preventive measure is related to the accommodation of the accused (suspect) in a residential area, there should be inviolability of his residence, the right to inviolability of private life, personal and family privacy. According to the Tokyo Rules in the 
application of non-custodial measures respected the offender's right to privacy, as well as the right to privacy of the family of the offender (Minimum standard of the UN. 1990).

The decision on the election in the house arrest as a preventive measure, the Court must specify not only the appearance but also the limits imposed on the face of the restrictions and/or prohibitions (p. 40 adopted by the plenum of the Supreme Court of the Russian Federation of 19.12.2013, № 41). So, taking the decision to ban the accused (suspect) which preventive measures in the form of house arrest, go beyond the dwelling in which he resides, the Court must specify the possible cases of lawful release of an accused person beyond a specified residential premise. But, unfortunately, the Court did not always comply with this rule. So, electing accused of having committed an offence of medium gravity, the preventive measure in the form of house arrest and entrusting of the defendant the prohibition extends beyond the dwelling in which he resides, except as provided by h. 8 art. 107 of the Code of criminal procedure, the judge did not specify these possible cases of lawful release of an accused person beyond a specified residential premise. In such circumstances, the Court of appeal changed the contested Decree specified the cases in which the accused may go beyond the dwelling in which he resides: treatment in emergency cases to medical facilities, police and rescue Services (Perm Krai Court ruling on appeal. 2013).

Prohibiting the suspect or accused communicating with certain persons, the Court shall specify the data to identify those individuals. But not always in practice, this obligation faithfully executed court decision makers regarding the election of house arrest as a measure of restraint (Appellate decision. 2014).

Page 108
Analyzing practice of Perm Krai Court for 2011-2016, it can be concluded that the courts, in the election of house arrest as a preventive measure imposed on the accused (suspect) the following prohibitions and restrictions: a ban on communication without the permission of the pre-trial investigation authorities with certain persons; the prohibition to leave the dwelling without the permission of the investigator, except in cases specified by law; communicate with persons relevant to the criminal matter; negotiate, using all means of communication on the circumstances relating to criminal proceedings; send and receive parcels, packets, letters and telegrams (Perm Krai Court ruling on appeal. 2014).

When restricting outside residential premises where the suspect or accused resides, the Court should enumerate the cases in which a person is allowed to leave the residential premises (for example, for walks, for attendance), and specify the time within which a person is permitted to be outside of the place of performance of a preventive measure in the form of house arrest. In addition, the Court should also specify the eases in which a person is prohibited from leaving the residential premises (for example, at night or other times during mass events or some of them).

When the ban on the use of communication facilities or restrictions on their use, the Court should explain to the suspect, the accused his/her right to use of the telephone to call an ambulance, law enforcement, emergency services in the event of emergency. Also, in accordance with part 8 of art. 107 of the Code of criminal procedure the accused have the right to communicate with the supervisory authority, by the investigator and the need to inform the supervisory authority of each case.

I think that, in extremely urgent situations, the accused (suspect) has the right not to comply with the restrictions and 
prohibitions for the salvation of life, health, property and relatives living with him in the same apartment. Furthermore, it is clear that the suspect, the accused could not be isolated from the defence lawyer and a legal representative. To communicate with them, including through telephone and other communication, house arrest is not applied. But the accused (suspect) must inform the supervisory authority about every call.

When applying restrictions on the accused (suspect) in the use of information and telecommunication network "Internet" Court should specify the cases in which a person is allowed to use this network (for example, for the exchange of information between the individual and the institution-if the suspect or accused is a student of this institution).

In our view, it is impossible to disparage the limitations and prohibitions specified in art. 107 of the Code of criminal procedure. If you do not monitor compliance by the accused (suspect), he could have an impact on the course of the preliminary investigation. For example, through a worldwide network of the Internet, the accused (suspect) could threaten witnesses or victims in a criminal case, thus forcing them to testify.

As the body is obliged to control the accused (suspect), in h. 10 art. 107 of the Code of criminal procedure specified the Federal Executive authority which carries out law enforcement functions, the functions of control and supervision in the sphere of execution of criminal punishments for convicted-the Federal Penal Correction Service (FSIN) has an obligation to provide technical tools and explain the rules of their detainee operation (Resolution of Government of RF. 2013).

Meanwhile, as noted in the legal literature, real security law enforcement relevant audiovisual, electronic and other technical means of supervision and control fall behind tumultuous and not always coherent development of lawmaking (Alexandrov, A. 2011). Also, there are cases where the accused (suspect) overcome under art. 107 of the limitations and restrictions of intentionally damages the technical device. So, Perm Regional Court, having considered the civil case at the suit of the Federal State institution «Criminal Executive inspection of main Department of federal service of execution of punishments on the Perm edge» to Popova on compensation for material damage, decided to collect the latest damage in the amount of one hundred and nineteen thousand seven hundred and eighty rubles for inadvertent damage to mobile control device. The decision stated that Popova had not taken adequate measures to preserve the device during a fire (Data from the site RosPravosudija . 2016).

\section{CONCLUSION}

Summarizing the above, it should be stressed that problematic aspects raised by the election and the use of house arrest as an alternative to detention measure should draw attention, first and foremost, a legislator and his focus on improving existing legislation that will reduce the number of errors allowed by the authorized bodies when electing the most stringent preventive measures in criminal proceedings, the enforcement of the constitutional rights of individuals in Russia. 


\section{REFERENCES}

[1] Alexandrov, A.S. (2011). House arrest: a critique of proposals to change $\mathrm{RF} \mathrm{MJ}$ calendar. Art.107 of the Criminal Code. Actual problems of criminal proceedings. M.: Uniti-Dana, 227.

[2] Appealate decision of the judicial Board on criminal cases of Perm Krai Court of 25.06.2013 № 22-5052. Retrieved from http://oblsud.perm.sudrf.ru.

[3] Appellate decision of the judicial Board on criminal cases of Perm Krai Court dated 24.01.2014 № 22-903. Retrieved from http://oblsud.perm.sudrf.ru (date: 14.08.2016).

[4] Appellate decision of the judicial Board on criminal cases of Perm Krai Court dated January 1, 2014 № 22-903. Retrieved from http:/oblsud.perm.sudrf.ru.

[5] Chapters 5, 26 of the Federal law of the Russian Federation «On the fundamentals of protection of the health of citizens in the Russian Federation» of 21.11.2011 g. № 323-FZ (amended by the Federal law of the Russian Federation dated 03.07.2016 g. № 286-FZ) // Rossiyskaya Gazeta. 2011. 23 November.

[6] Convention on protection of human rights and fundamental freedoms of November 04 . 1950), amendments of May 13, 2004; Protocol № 1, signed in Paris 20.03.1952, Protocol № 4, securing certain rights and freedoms other than those already included in the Convention and the first Protocol to it (signed

[7] Data from the site RosPravosudija. Retrieved on May 21, 2016 from https: / rospravosudie.com/courtpermskij-rajonnyj-sud-permskij-kraj-s/act487078669.
[8] Decision of the Constitutional Court of the Russian Federation "On case on inspection of constitutionality of some provisions of the Criminal procedure code of the Russian Federation regulating the order and terms of application as a preventive measure of detention on stages of criminal proceedings

[9] Decision of the plenum of the Supreme Court of the Russian Federation «On the courts to apply the legislation on preventive measures as detention, house arrest and bail» of December 19, 2013 № 41 (in the redaction of the plenum of the Supreme Court of the Russian Federation of May 24, 2016. №23). Th

[10] Main statistical indicators of the courts of general jurisdiction for the first half of 2016. (2016). Retrieved from http://www.vsrf.ru.

[11] Main statistical indicators of the courts of general jurisdiction for the first half of the year $2016 . \quad$ Retrieved from http:// www.vsif.ru.

[12] Minimum standard of the UN rules with respect to non-custodial measures (the Tokyo Rules). Adopted by the UN General Assembly resolution of December 14, 1990 №45/110, p. 3.11). Retrieved on August 14, 2016 from ATP «Consultantplus».

[13] Part 1. Article 2 of the Federal law of the Russian Federation «On migration registration of foreign citizens and stateless persons in the Russian Federation» of July18, 2006 № 109- FZ (amended by the Federal law of the Russian Federation on 28.11.2015 № 358-FZ). Rossiyskaya Gazeta. 2006. July 20.

[14] Perm Krai Court ruling on appeal of 02.06.2014, № 22-4319. Retrieved on 
August $\quad 14, \quad 2016$ from http: oblsud.perm.sudrf.ru/modules.php.

[15] Perm Krai Court ruling on appeal of June 12, 2013 № 22-9668. Retrieved from: http:oblsud.perm.sudrf.ru/modules.php.

[16] Perm region security measures as detention, house arrest and bail, including minors, for year 2015. Retrieved from http:// oblsud.perm.sudrf.ru.

[17] Reference on Results of practice of the courts of the Perm Krai as security measures as detention, house arrest and bail, including minors (2013). Retrieved from http://oblsud.perm.sudrf.ru.

[18] Reference on the results of practice of courts of Perm Krai preventive measures as detention, house arrest and bail, including those against minors for 2013 (2013). Retrieved from http://oblsud.perm.sudrf.ru.

[19] Reference on the results court practice of Perm Krai on preventive measures as detention, house arrest and bail, including against minors for 2013. Retrieved from http://oblsud.perm.sudrf.ru.

[20] Reference on the results of practice of the courts of the Perm region security measures as detention, house arrest and bail, including minors (2015). Retrieved from http://oblsud.perm.sudrf.ru.

[21] Reference on the results of practice of the courts of the Perm region security measures as detention, house arrest and bail, including minors, for year 2015. Retrieved from http://oblsud.perm.sudrf.ru.

[22] Reference on the results of the practice of the courts of the Perm region security measures as detention, house arrest and bail, including minors, for 2015. (2015).
Retrieved from http://

oblsud.perm.sudrf.ru.

[23] Reference on the results of the courts of the Perm Krai security measures as detention, house arrest and bail, including minors (2015). Retrieved from http://oblsud.perm.sudrf.ru.

[24] Report on the work of the courts of general jurisdiction to hear criminal cases for 12 months (2015). Retrieved from http://www.vsrf.ru.

[25] Report on the work of the courts of general jurisdiction to hear criminal cases for 12 months 2015 Retrieved from http://www.vsrf.ru.

[26] Resolution of Government of $\mathrm{RF} \ll \mathrm{On}$ medical examination of suspected or accused of committing crimes» (along with «rules of medical examination of the suspected or accused of committing crimes») on 14.12.2011 № 3 (as amended by the Decree of the Government of the Russian Federation dated04.09.2012 g.

[27] Resolution of Government of $\mathrm{RF}$ «On audiovisual, electronic and other technical means of control that can be used to monitor the presence of the suspect or the accused in a place of execution of preventive measures in the form of house arrest and they imposed Court bans and/or restrictions» (along wi

[28] Statistics for the judicial division of the Supreme Court of Russian Federation. Retrieved from http://www.cdep.ru.

[29] The Code of Criminal Procedure of the Russian Federation adopted by the State Duma of the Federal Assembly of November 22, 2001 № 174-FZ (amended by the Federal law of the Russian Federation of July 06, 2016, № 375-FZ: The Rossiyskay Gazeta, of December 22, 2001. 
[30] The Constitution of the Russian Federation of December 12, 1993: Amendments to the Constitution of the Russian Federation of 30.12.2008, № 6FCL; 30.12.2008, № 7-FCL; 05.02.2014, № 2-FCL, 21.07.2014 №11-FCL; 2008, 2014, № 31. Art. 4398.

[31] The ruling of the ECHR in the case of Evgeny Gusev (Yevgeniy Gusev) v. Russian Federation (complaint ㄲo 28020/05 of December 15, 2013)/Russian Chronicle of the European Court of Justice. 2014. № 4.

[32] Tkachev, N.V. (2003). Theory and practice of application of coercive measures not involving imprisonment: Diss... Cand. legal. Sciences. Chelyabinsk South Ural State. University, P. 248.

[33] Zjablina, M.V. (2016). Modern problems of ensuring the right of suspects and accused persons to liberty and security of person. Russian justice. № 6. P. 33 . 